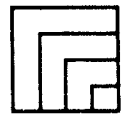

AllIM
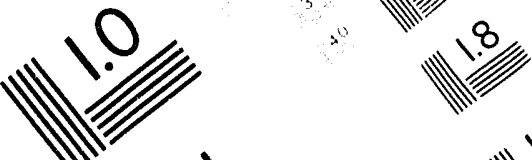

Association for Information and Image Management

1100 Wayne: Avenue. Sulte 1100

Silver Spring. Maryland 20910

$301,587-8202$

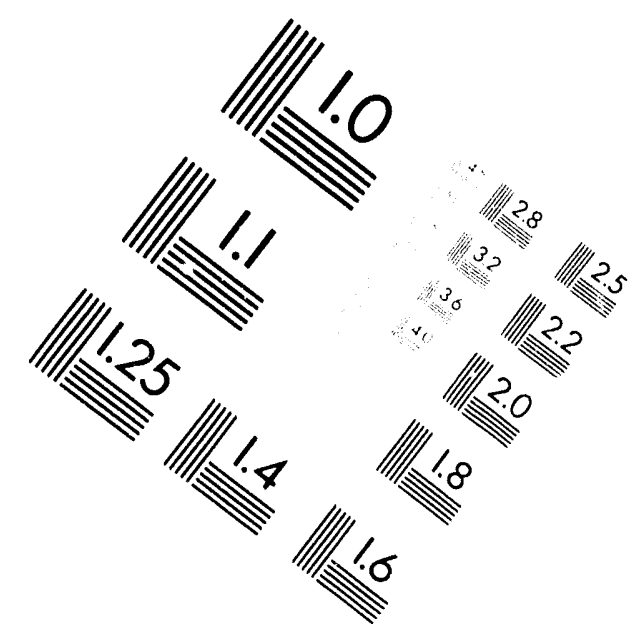

\title{
Centimeter
}

$\begin{array}{llllllllllllllll}1 & 2 & 3 & 4 & 5 & 6 & 7 & 8 & 9 & 10 & 11 & 12 & 13 & 14 & 15 & \mathrm{~mm}\end{array}$

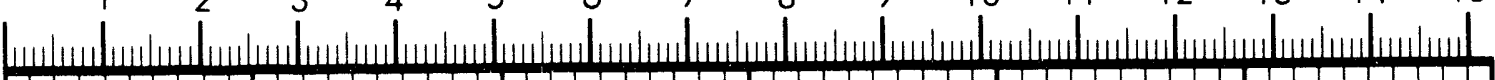

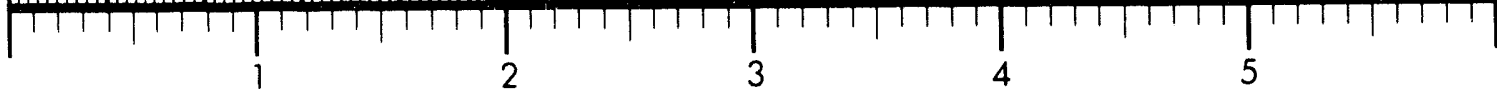
Inches
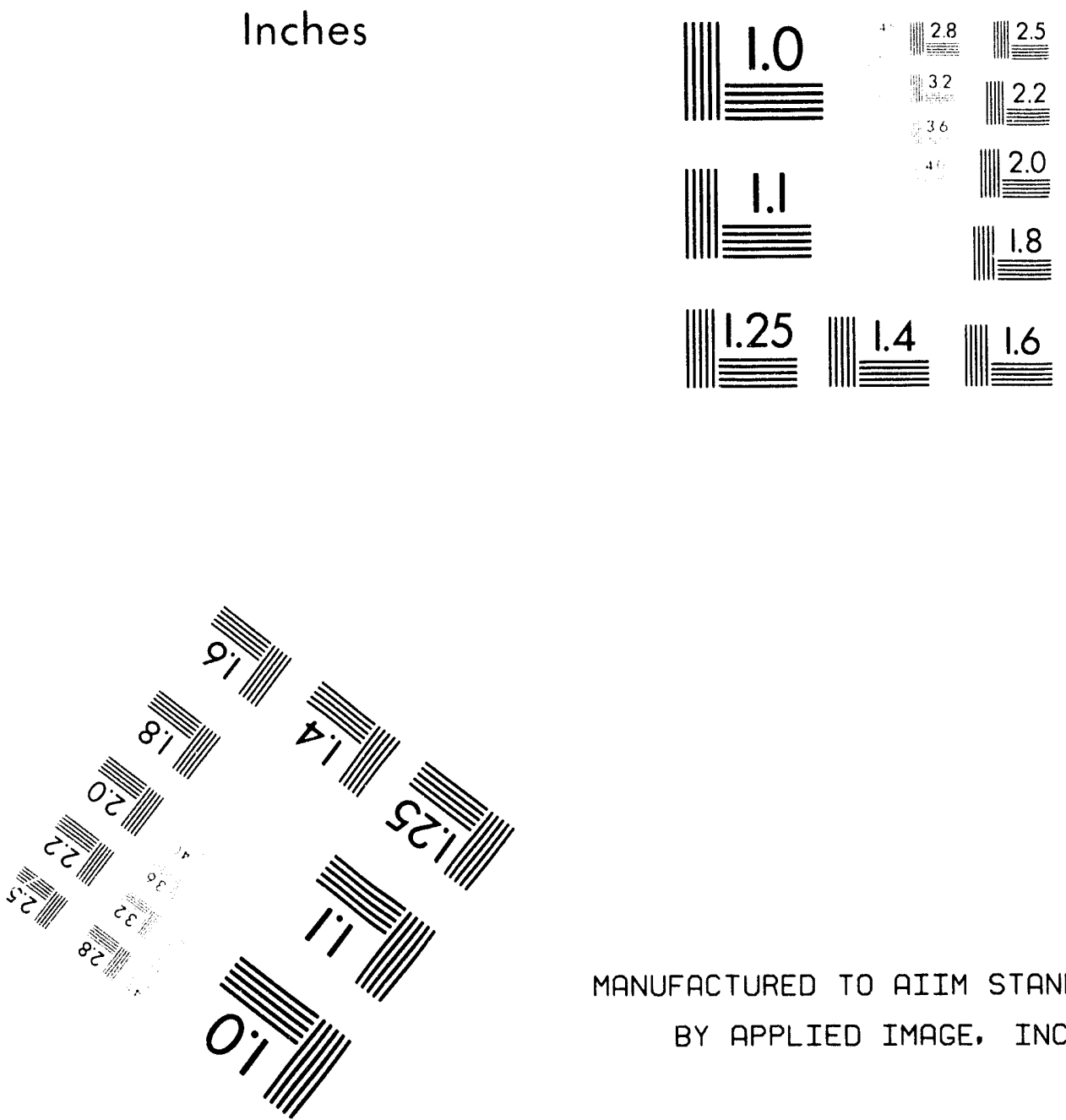

MANUFACTURED TO AIIM STANDARDS

BY APPLIED IMAGE, INC.

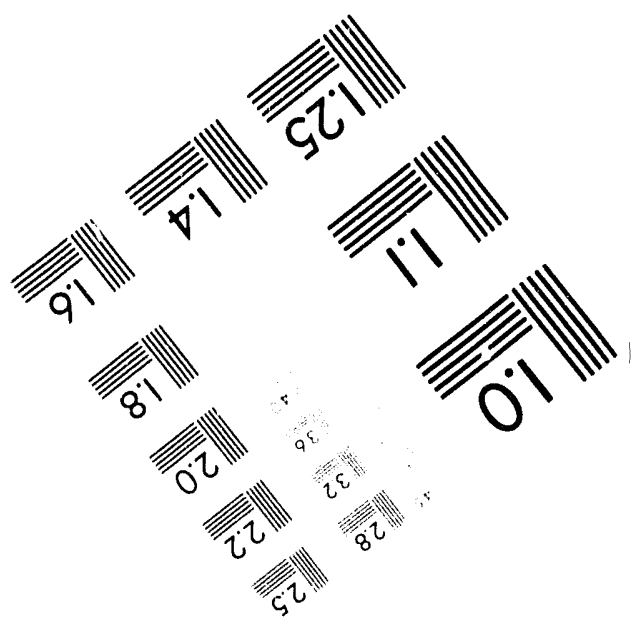



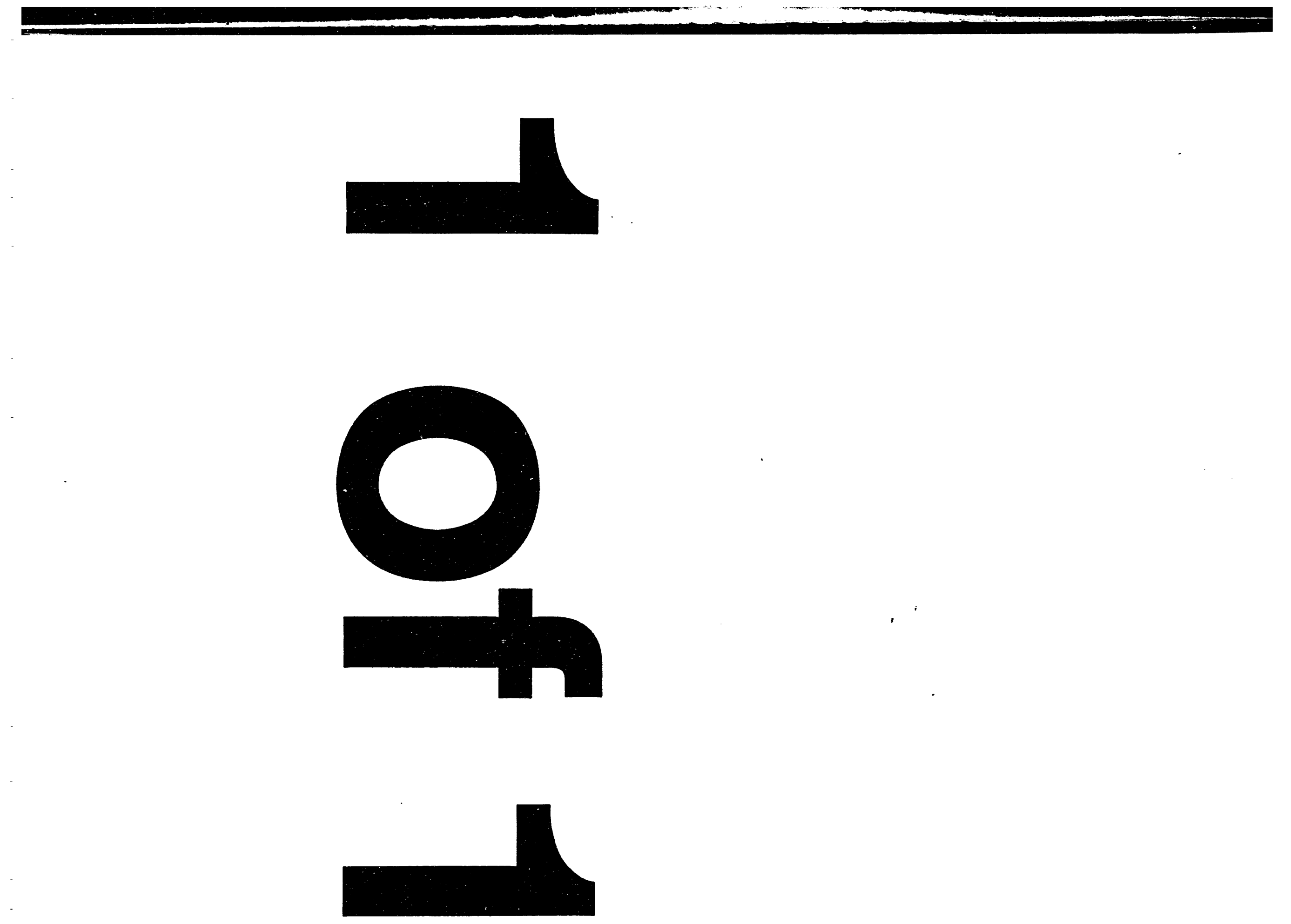


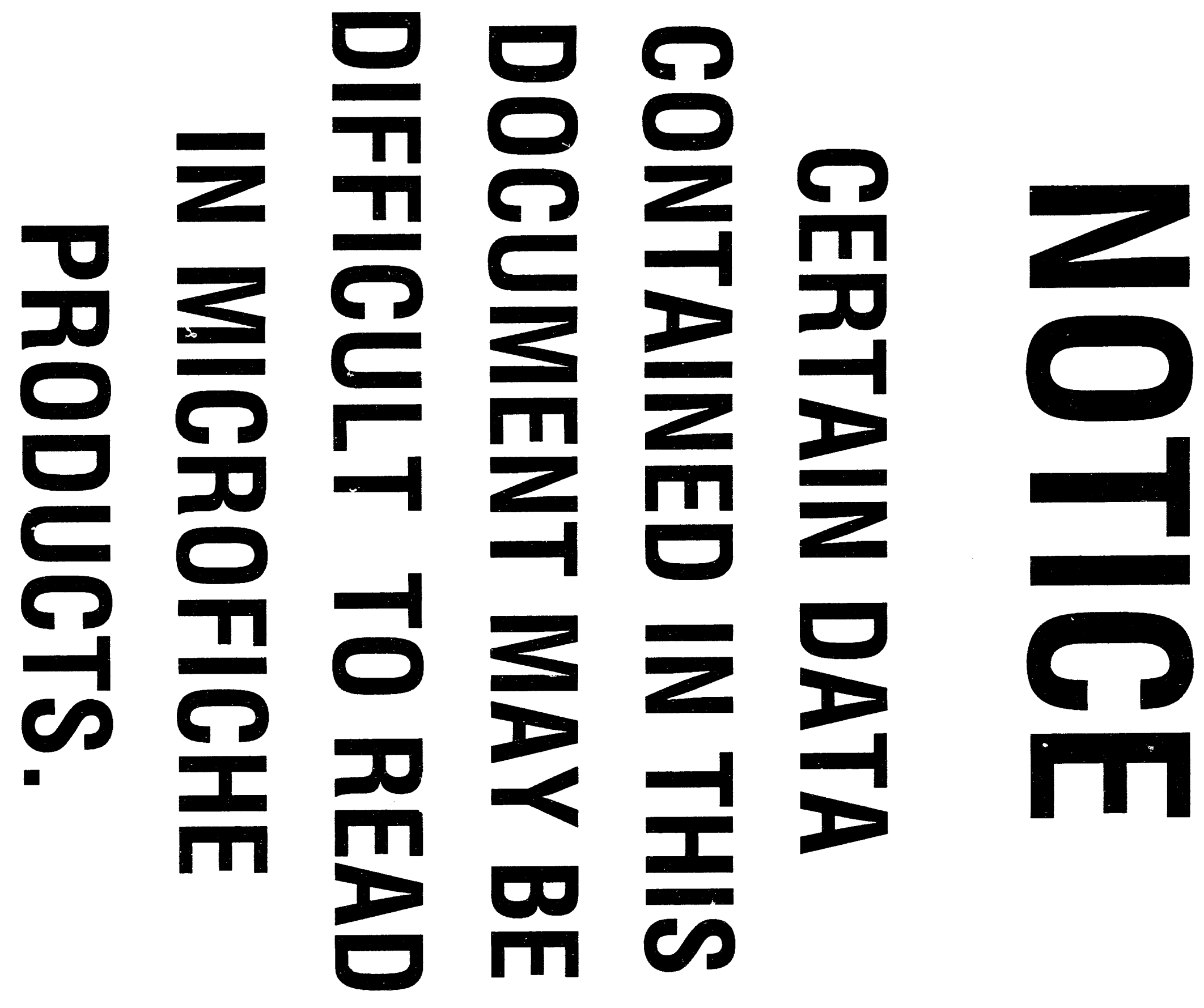




\section{$* w-18041$}

WELLSPSFE

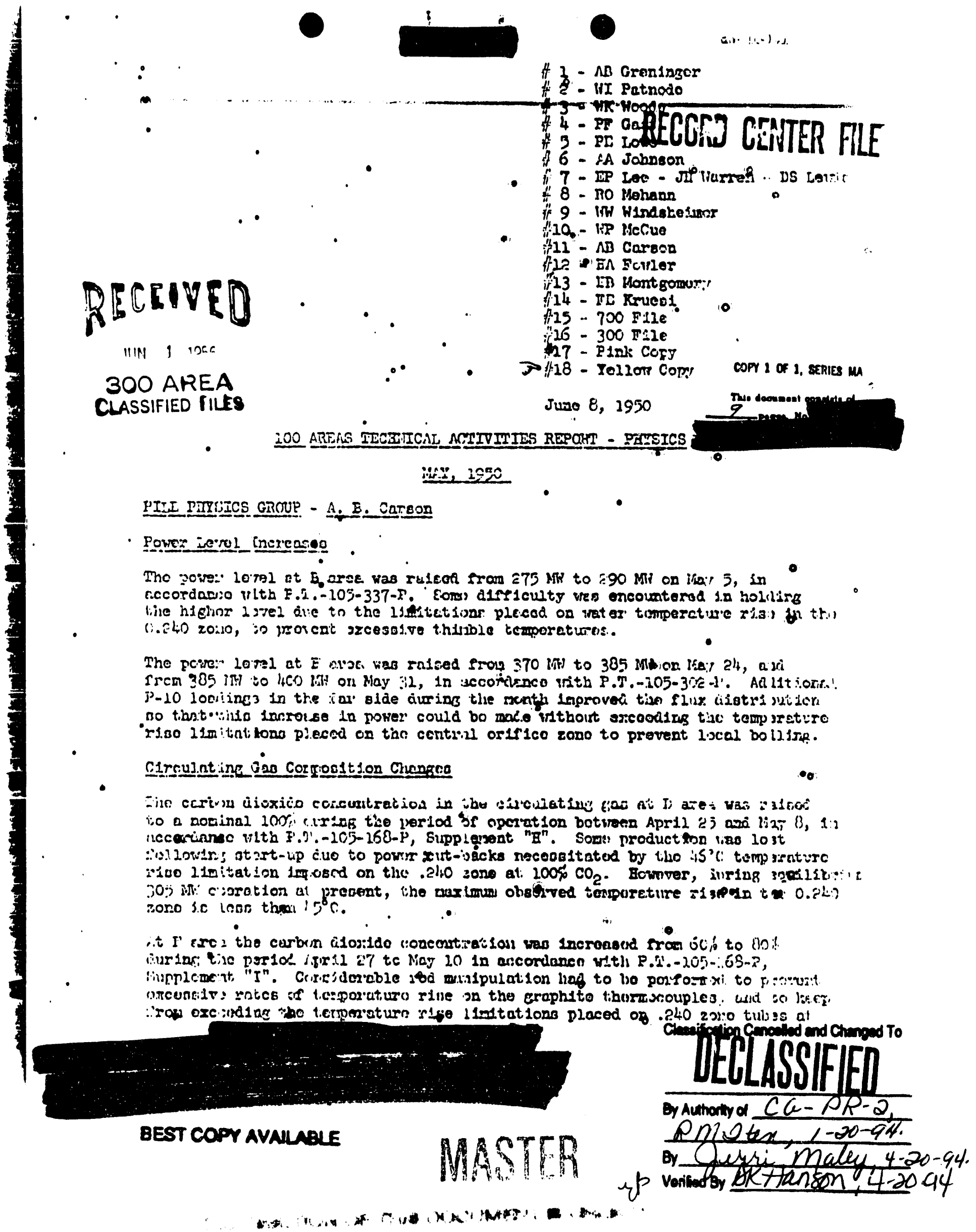




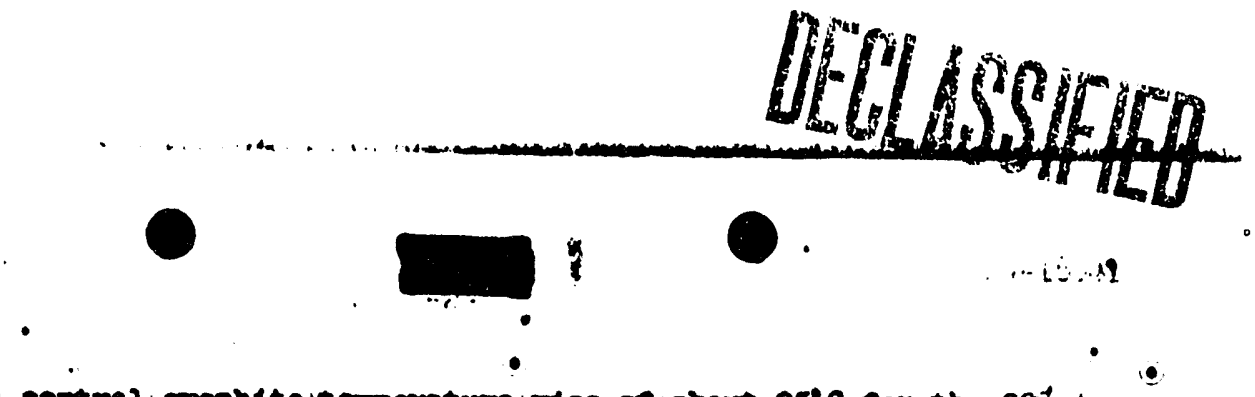

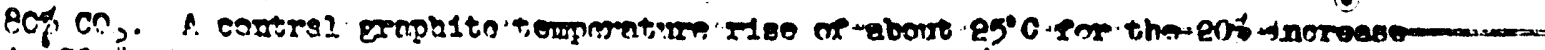

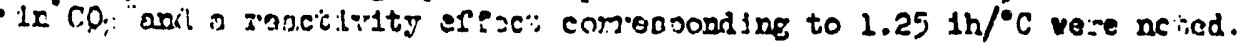

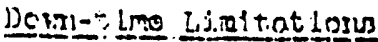

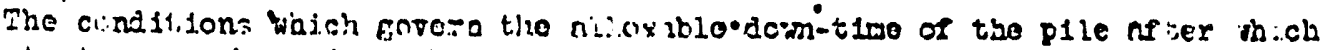

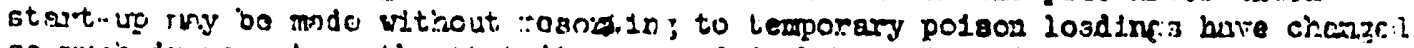
30 rul:i lil recent wonths that 1 ticers advisablo to frelude a eurr.s.t mw mary

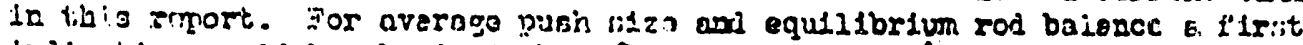
l.ndicrition would bo obtaloed ntout 23 kouno aftor thé unlt 18 heis-inj dirns at I and sieas. Ni $n$ arsa tlis woll.a ve atour one hour longer. Ix ordur to kcely ine deartifity trnnelent with:s the powar of the control rod sybtem tho

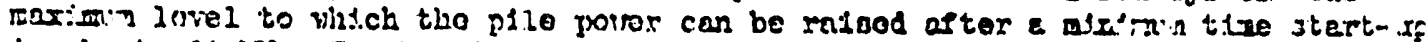

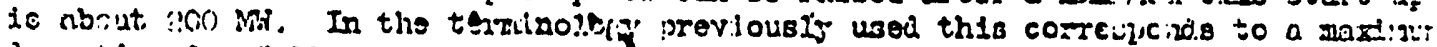

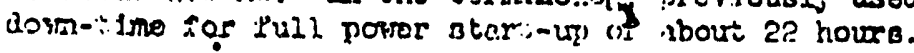

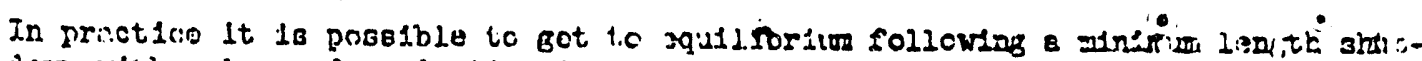

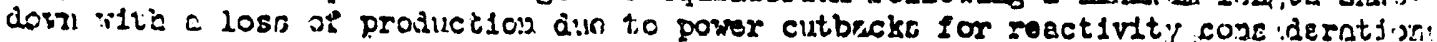

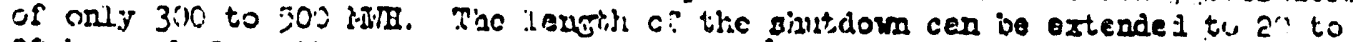
30 ilciro heforo tise produst10:2 looi d io to thone conslderations renches he

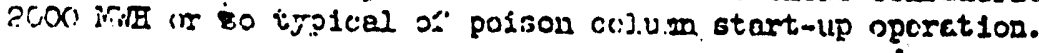

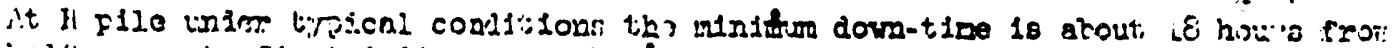

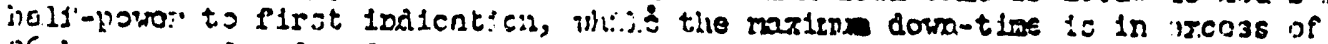

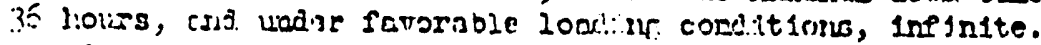

mest. Iac1:1t19a

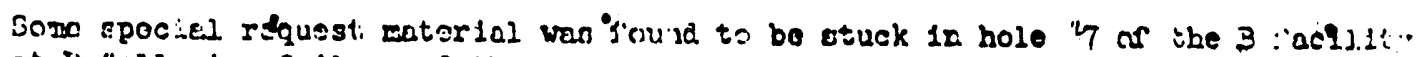

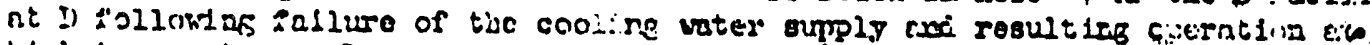

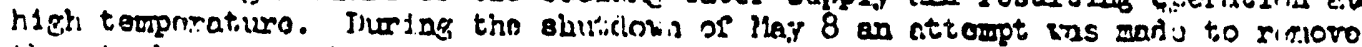

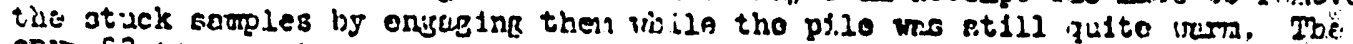

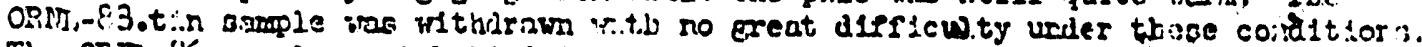

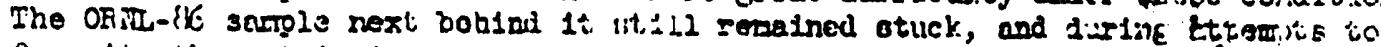

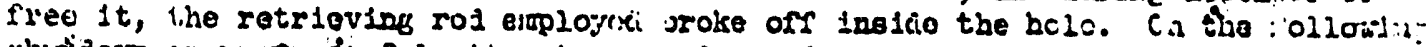

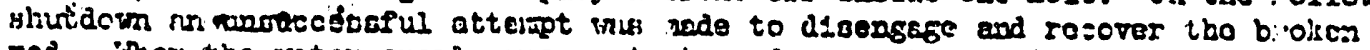

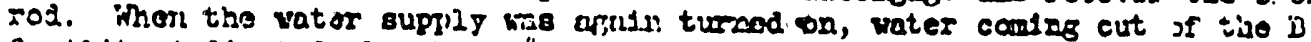

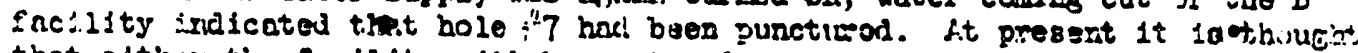
that. eltisis tho faclilty H1ll be replacod or that the pumetured he all. be

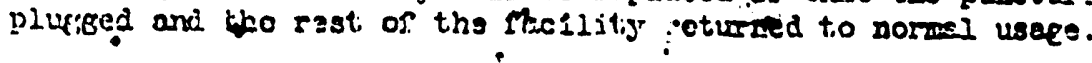

At $F$ area durine the shutdors of liuv 33, the ral of the $E$ bele tne sac1.1ty

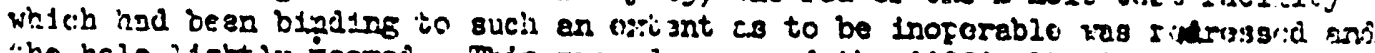

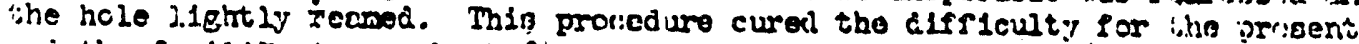
ind tl:s fivill1oy 10 noy back th noszoi operation.

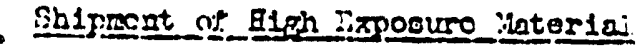

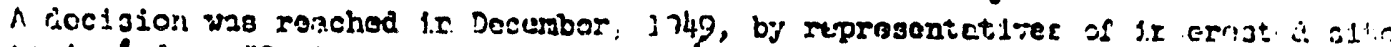

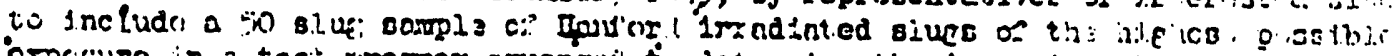

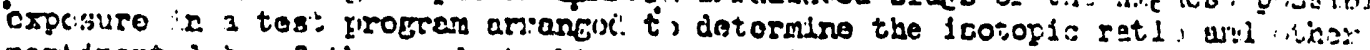

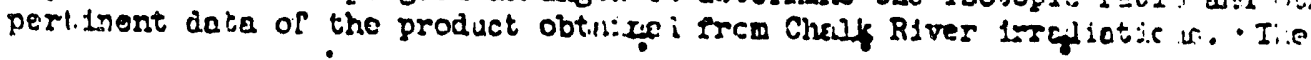



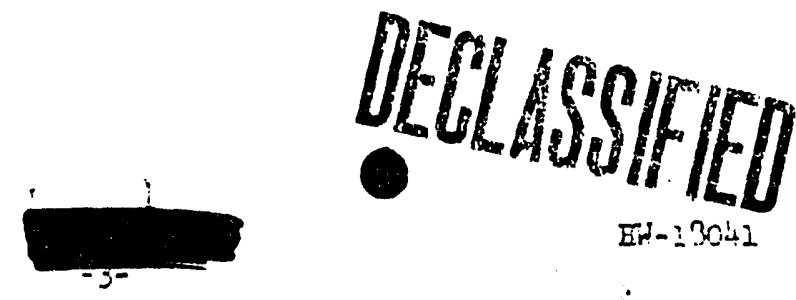

End- : $30 \mathrm{~d}+2$

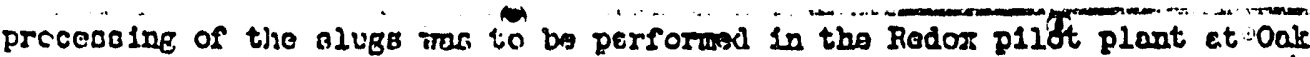
Piicige: Theis proponed scibolule cellied for the Harford toterial to be delivejed thero vilh at lasot $90 \mathrm{dras}$ ccoling by the f1rst. wook in Jumo. The cooll.ng forlod concilt 102511 witod tilo choicc of moitorlal to that pushed before Morch 1.

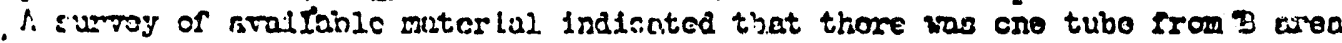

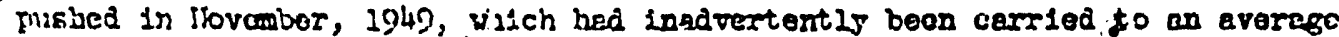

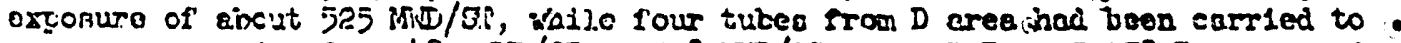

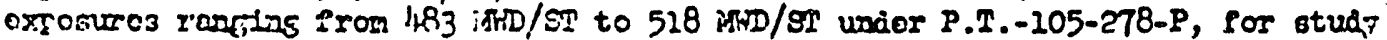
of irfadiation effect. st $h i$ isher exposures. Thls materlal was taged ond set a.3ide for exaninntion by Te.junical. The naterial from B area vas inadvertentis cin1poed to 200 aren for pro:seasing et one time but kas rocovered at cons1derable

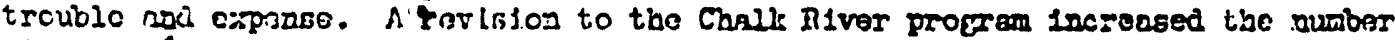

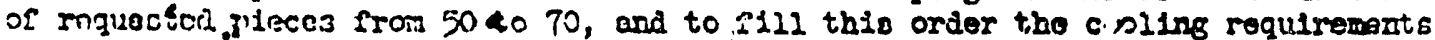

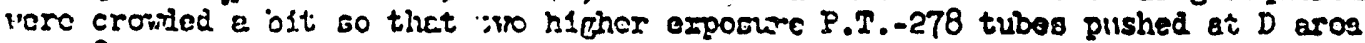
on 3-b-50 couid bo inclueded. Osing thrae sources, 70 pleces sere obtalner, 18

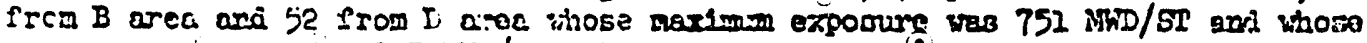

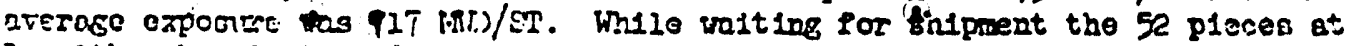
I, althoigh well taused con labelied, rero ehipped to B by mistalse and upon return v250 mised inth misci32lasoous recent discharte nnterial and oh1opod to

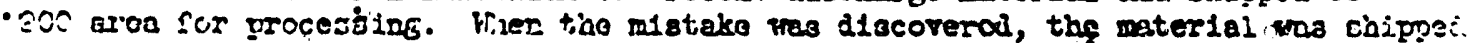

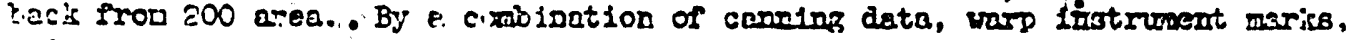
ini veass l readines, 30 or :he nore deoirable of the 52 plecos vore resorered.

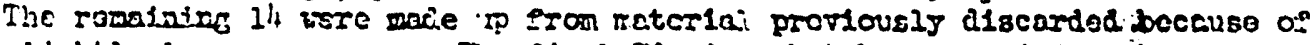

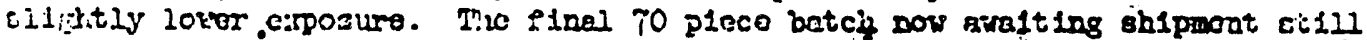

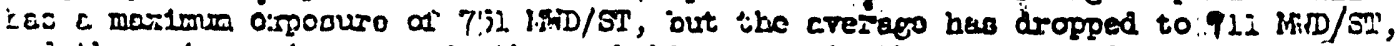
cin there 18 en increcoo in the nrobable error in the exposuro date fron parasps - $\quad$ iri, teo probably $10 \%$.

Sracini ing-uent Slrmagy

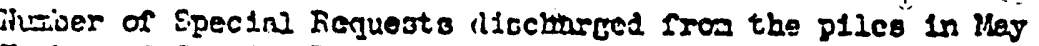
inuber of spesinl kequeots sharged Into the piles in thy jiuzber of Specinl fiequests im hend to be luradiated.

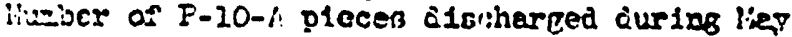
Tirber of P-10-A pleces choiged durlog lay

\section{:}

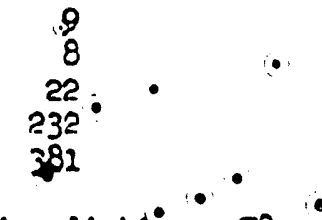

Tisare aro at prosont 45 inhuurs taken up in materialo testing 1rradietiono, 73 in I3otopo Prodiction 1rrad!lotions, and 12 in Geroral Research irrealationa. 
Roact 1rit. Bal ance

The roactivity otntus of the p1loo at tho begioning and ond of the month of May 13 olmorizod holox.

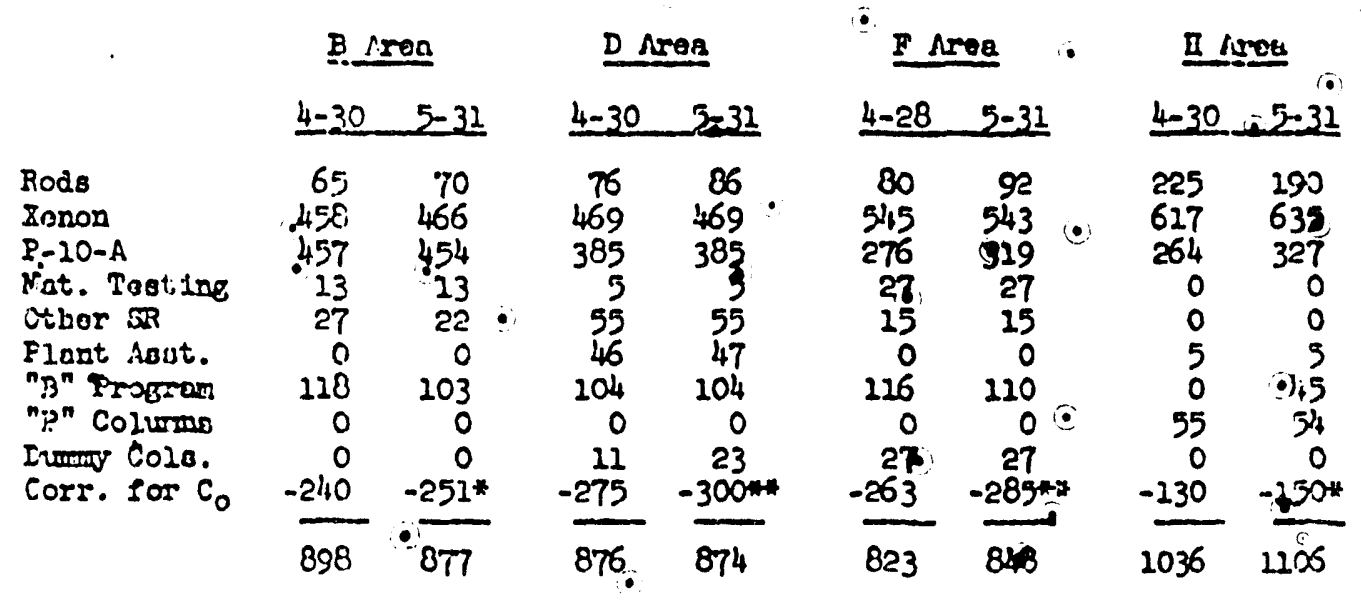

- At. 3 nnd 8 tho ovorall coefficlent contributions vore revised to cormiopond

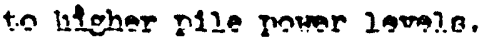

14 At $D$ and $I$ the overoll coerficlent contribut lons were reviaed to conform witis oborrod roactivity effects of 1acreaned $\mathrm{CO}_{2}$ concentration.

The roictivity eifocto noteid vere in rough afooomont with the expected offact ". co varletions in product concoutration.

F-11 FROJPI - F. E. Brued

- Errerimental

Iuring the provsoun roport periad the olght lnch dieweter cylinarical roactior

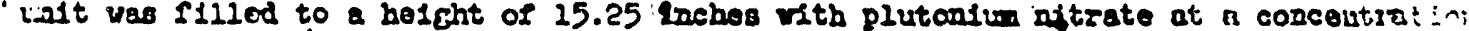
of 77.4 Gram Pu/liter usthout obtoining crit1cality. Since that tim further

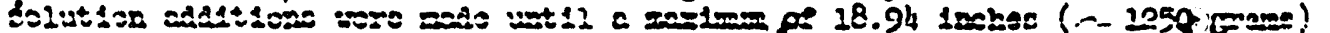
vas resched, th1s beins the lindt of the reactior unit. The system vas sub-crlivice: c.t th1s he1ght. Invarso mult1plicat10n-801ut1on belont extrapolation ta crit1cel! could not be wade ulth ourficlont aceuracy to ascortaln shother an infinitely tell elfint Inch ronetor unit, can be esde critscal under the conditions of this - experiacent. 


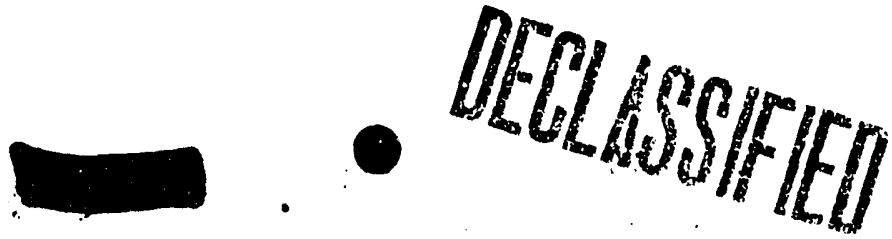

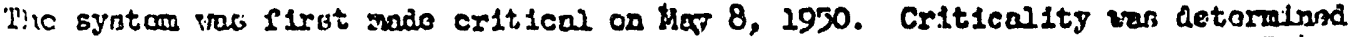

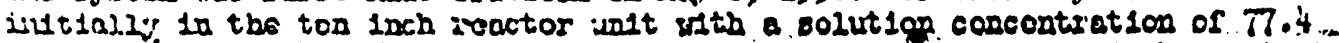
E:am Pu/litor. Doterninations were wado of the effectiveness of the control rso, mantrant tubo, end platco positioning beforo preceeding ifth experiments at hlahor (moro optimus) hyirazon to plutanium ratios. The following toble sumanrlice critlcal date obvalnod during tho wonth. Correctlons.hato beep weda for tho vold 1atroducal by tho control rod in the expertments at 77.4

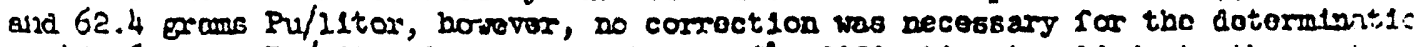
at 49.26 grams Fu/ 11 ter Que to a control rod mocificloation to elininate the vola. All oxporimats woro concluded after complete rithorateal of the rocutriant tube.

\begin{tabular}{|c|c|c|}
\hline 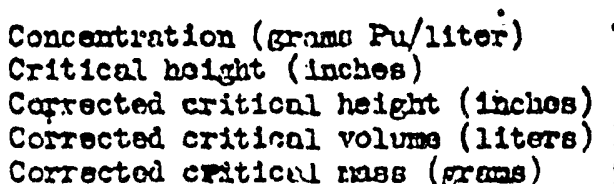 & $\begin{array}{l}77.4 \\
9.67 \\
9.47 \\
12.19 \\
94.2\end{array}$ & $\begin{array}{l}62.4 \\
10.65 \\
10.37 \\
13.37\end{array}$ \\
\hline
\end{tabular}

Theoret1cal - M. M. Mazox

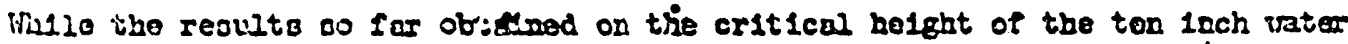
tamod eylinder at tiroe disrorent concentrations are not sufricient (un tiso bisis of procentiy lonorn tioory to determino the exact nuelear constents of pivitoniun, it appears quite cortain that the Fold-Slotin value for the minimur critical mass is too low.

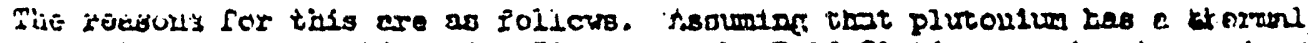
absorption croso-soct ion of 1150 barns, the Feld slotin experimont revoures, on tho bacis of Creslling's ILA-493 theory, that $\bar{Y}_{\mathrm{P}}$ (the number of rcutroas

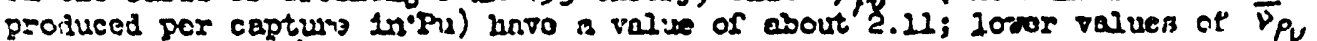

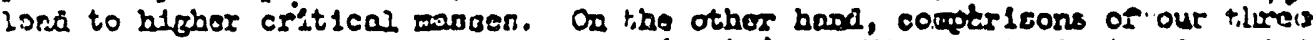

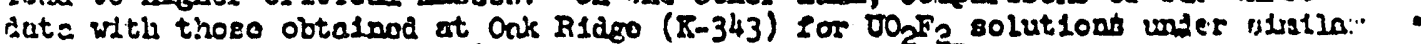

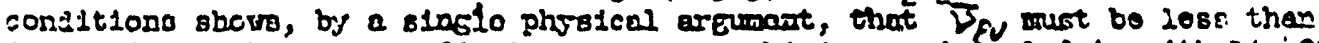

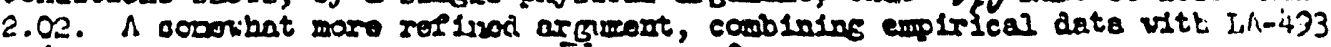
tinfory, soens to indicato tint $\bar{\nabla}_{P}=1.98$; this is the reluo comonly cecsptcrl in the project 11toraturo. As more oxperimontel orldence becores aval jables. 14: should bo Fossible t.o detamino Fpuqulte accuratels; s soporate report will be 183406 on tibla subjoct at the eppropresato $t 1000$.

\section{Enilpment Modificatian}

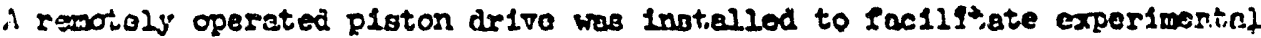

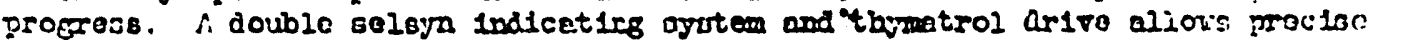
sattins of the pleton to about .010 inphes.

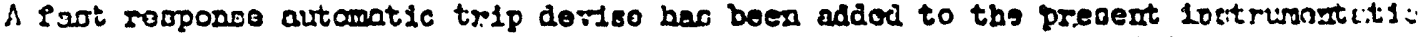
systec. Ta1o doviso is coupled inte tho prinary seram circuit snd $18 \mathrm{a}$

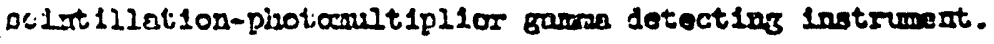

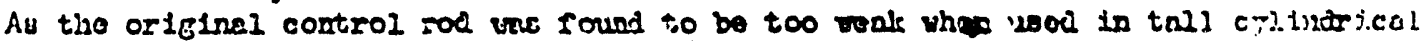

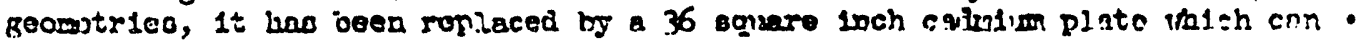
bo mpotaly poolt 10nod under tho roactor unit. Thu new rod apparontili w11 be sat lof setor, for tho doterminations contemplatgd. 


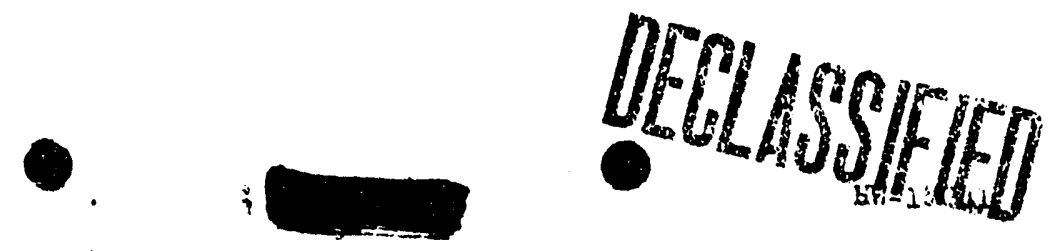

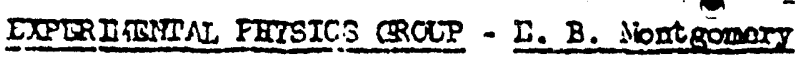

Test P110

A. J slug Tostion

Durlas Meg, 2900 "J" olues woro recelved. Since tho quallty of the "J" matertal has bescuse nore unform it ins botn fessiblo to sarple beats of those nlugs on a stestatical basis and roduce materialy tho anount of reactivityitosting:

$\Omega_{3}$ the reactirlty of the olus in the best neasure of 1 ts uronfum content, tho téct p1lo regults cen bo uBod for enterlal accountabling by the producor and

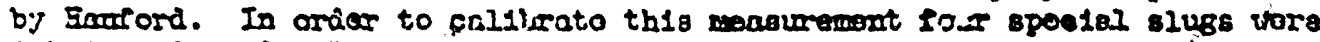
fabricated at Oak Ridgo for teat p1le moarurenant and subsequeni colploto

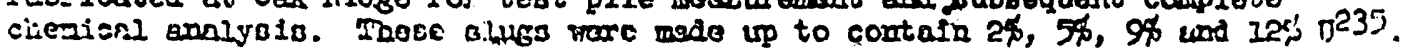

Tahle I - Weapurement of Boactivity of Four I Siuse

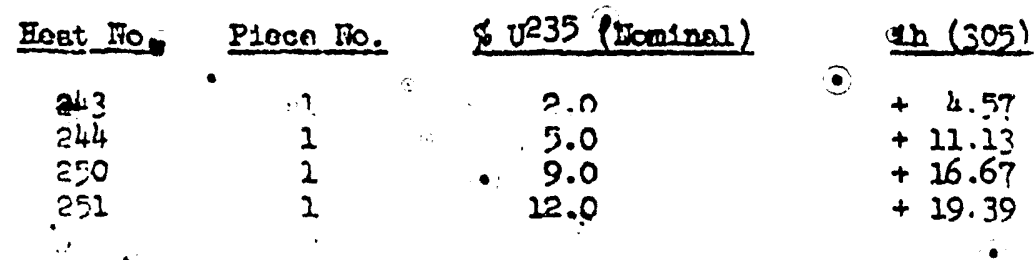

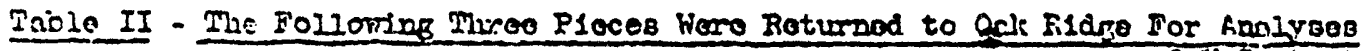

Inot To. , Flose Ifo. In $(305)$

$\begin{array}{lll}111 & 15 & +16.03 \\ 112 & 1 & +16.63 \\ 113 & 19 & +14.54\end{array}$

Tho corplete rocare of "g" Blus tosting from the begloning through May 31, 1950, is sisora in tho followlog tablo:

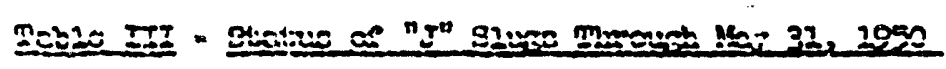

•

Sidporat Mo. Slugo Mo. Sluge
Tio.

1

12

2 - 300

3300

is $\quad$ g.0

- 51213

$\begin{array}{ll}0 & 1000 \\ 7 & 2500\end{array}$

$8 \quad 2400$
303 Teetse

\begin{tabular}{|c|c|c|}
\hline Canne & $\frac{\text { Wo, SLugs Ro }}{\text { Bara }}$ & Ho. E \\
\hline
\end{tabular}

iccorts:

$\begin{array}{rr}12 & * \\ 289 & * \\ 247 & * \\ 737 & 80 \\ 0 & 0 \\ 419 & 69 \\ 284 & 22 \\ \cdots & --\end{array}$

$\begin{array}{cc}0 & 12 \\ 19 & 279 . \\ 33 & 23.4 \\ 6 \cdots & 760 \\ \cdots & 36 \% \\ 0 & 86 \% \\ 0 & \cdots\end{array}$




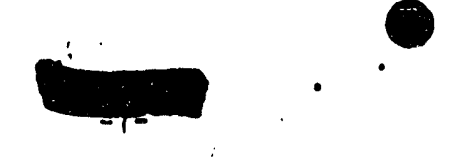

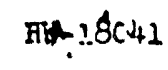

it These sluge maro cannd prior to 305 tosting.

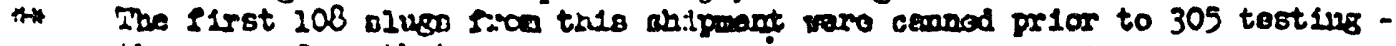
tinese ore freck that group.

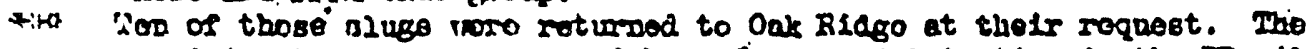

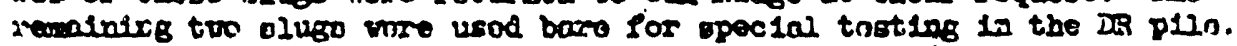

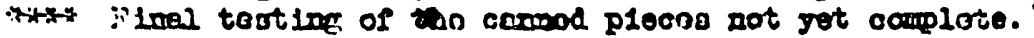

B. Teuting of 4.25 Inoh "Z" P10008

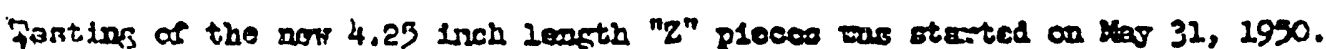

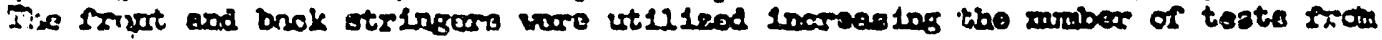

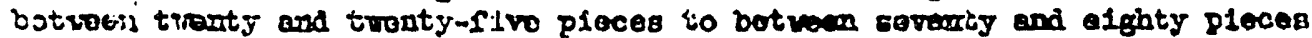
vor הar.

r. Sorscial Wurk Requesto

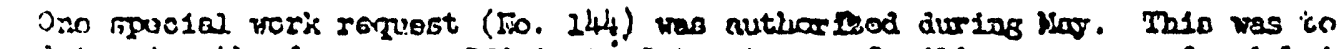

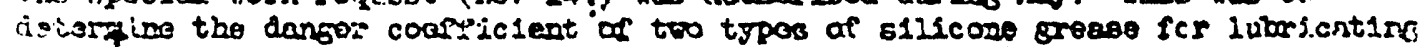

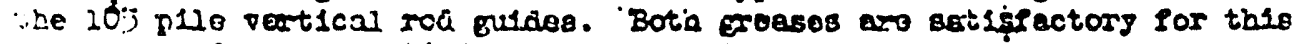
pinposs an far as ronctioltit is concersed.

$$
\begin{aligned}
& \text { Tab1e } \pi
\end{aligned}
$$

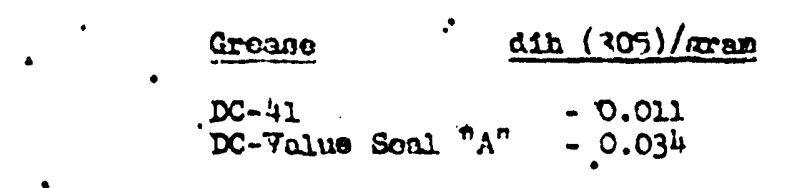

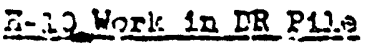

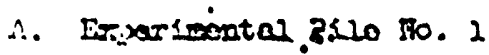

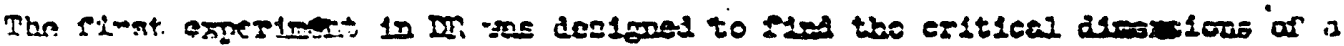

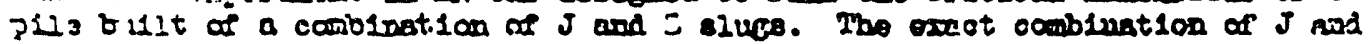

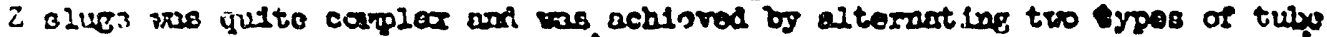

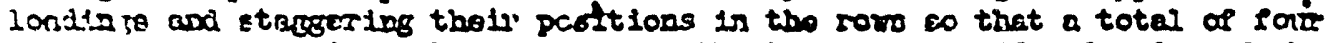
tilise t.pos reeulice if the posi:100 1.0 the tube vas considerse. Oner of the

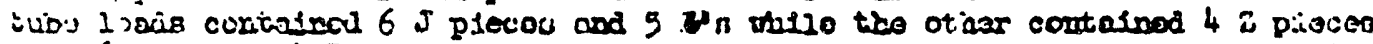

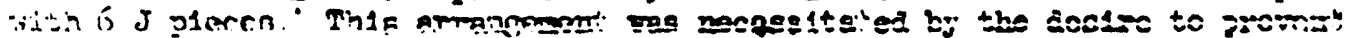

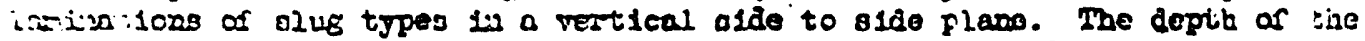

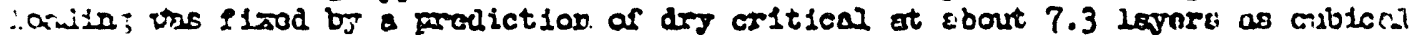

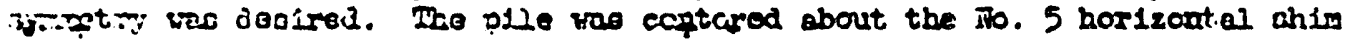

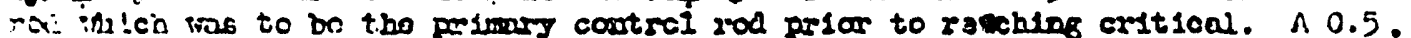

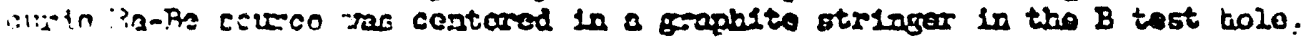

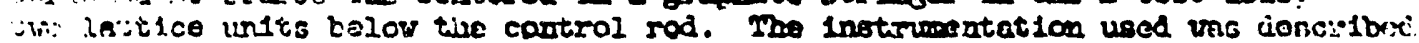
is ino northe ropart. 


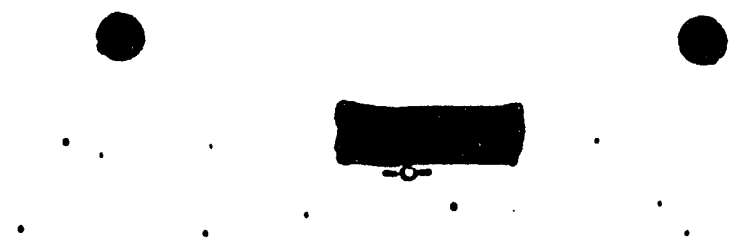

Tho loedint of the p1lo altomated above bued blot the cantriel centrol rod

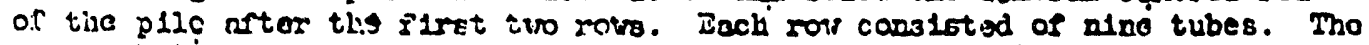

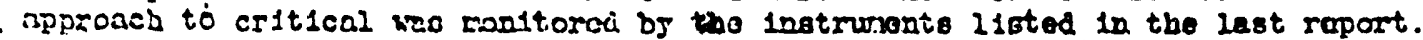

- in radition, four inlium foile wore irradiated in the "B" tust hole as ech

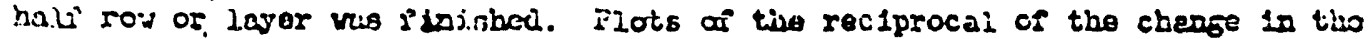
counts yer ininuto vfsisus tho number of larers londed earo a good oxtrapolatilon to eritical.

As tile validity of this oxtropolation irerecsed it was seen that critical

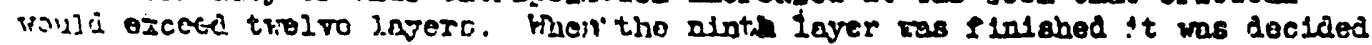
tis ridas tho pilo to tes tubes per iares. Critlcel vac reachod st botroon

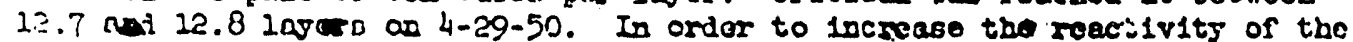
Whe two noro tubes roro aclied misias a total of thirtesn lavare af ten tubss cich. At thls tho ine excoss recet101t,y wos about 27 inhours. -

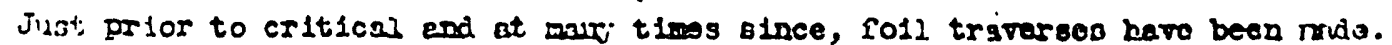
Praforses to detarnice the efroctive 6120 of tho pilo, the nentran distribicion in cello and Glugs, and the pover level or tho pile hate given rige to a lasgo mins of deta witith can't consiclored is docell hero..:

hifur critiçal ras roncher tio control rols were calibrated to provide.adorurte cisnirol at $i$ level a sern:al vatts for foll irradietlons. Danger cuefficiont

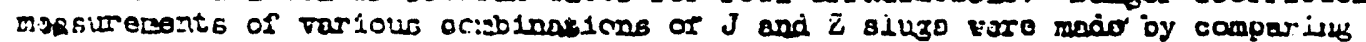
perlod soseliretouts as the "Flandard bare pile" witis the perlode of the pil.3 Tili: tbo somple inocted is o tube.

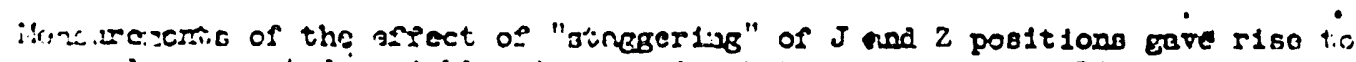

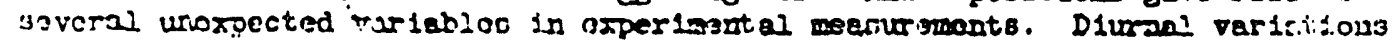

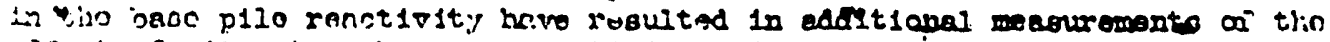
erícet of pile atmorpiere an reactivity, as watey proseuro an rosctivity: suis.i. crrors is positionlars of charges, otc., otis.

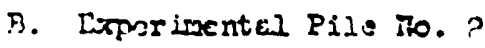

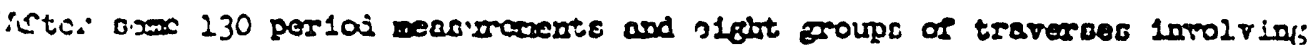

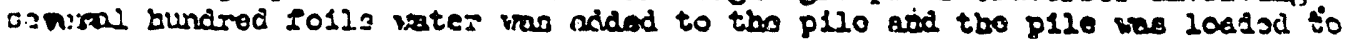
wet critical urife the soos techplques as far tho dry p110.

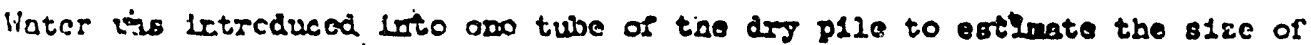
the vet pile. Noter thlo, water pro adjod to two rows at a tims unt il the

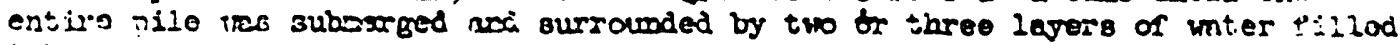
tiates.

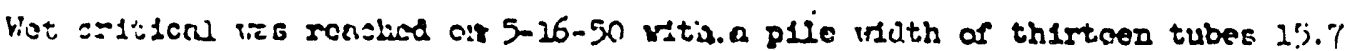

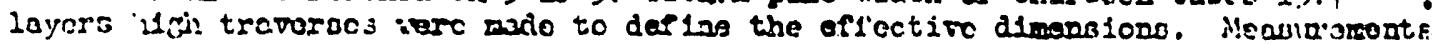

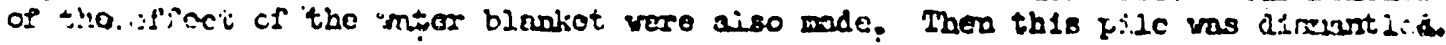




\section{DEQLASSIFIED}

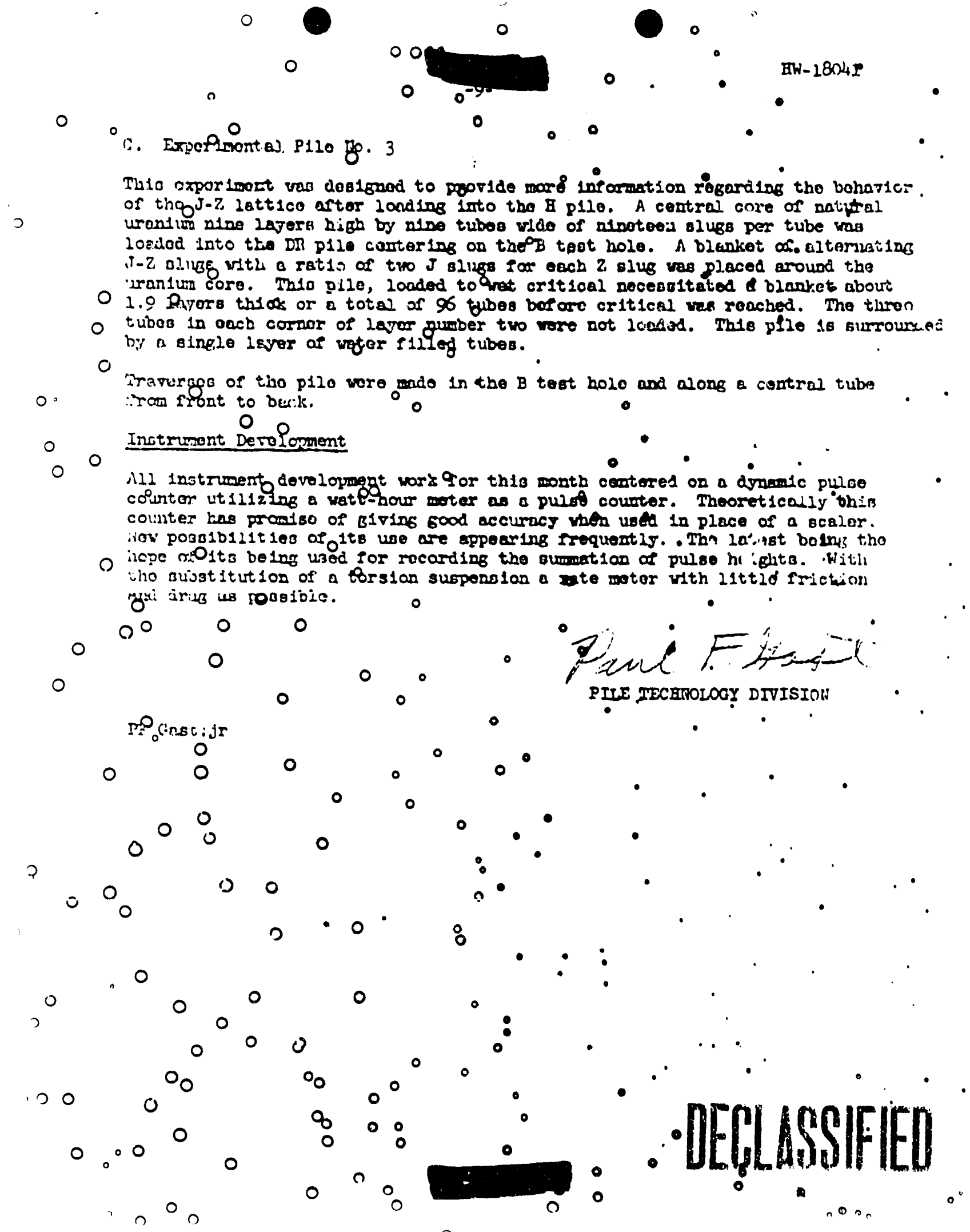


DOCI
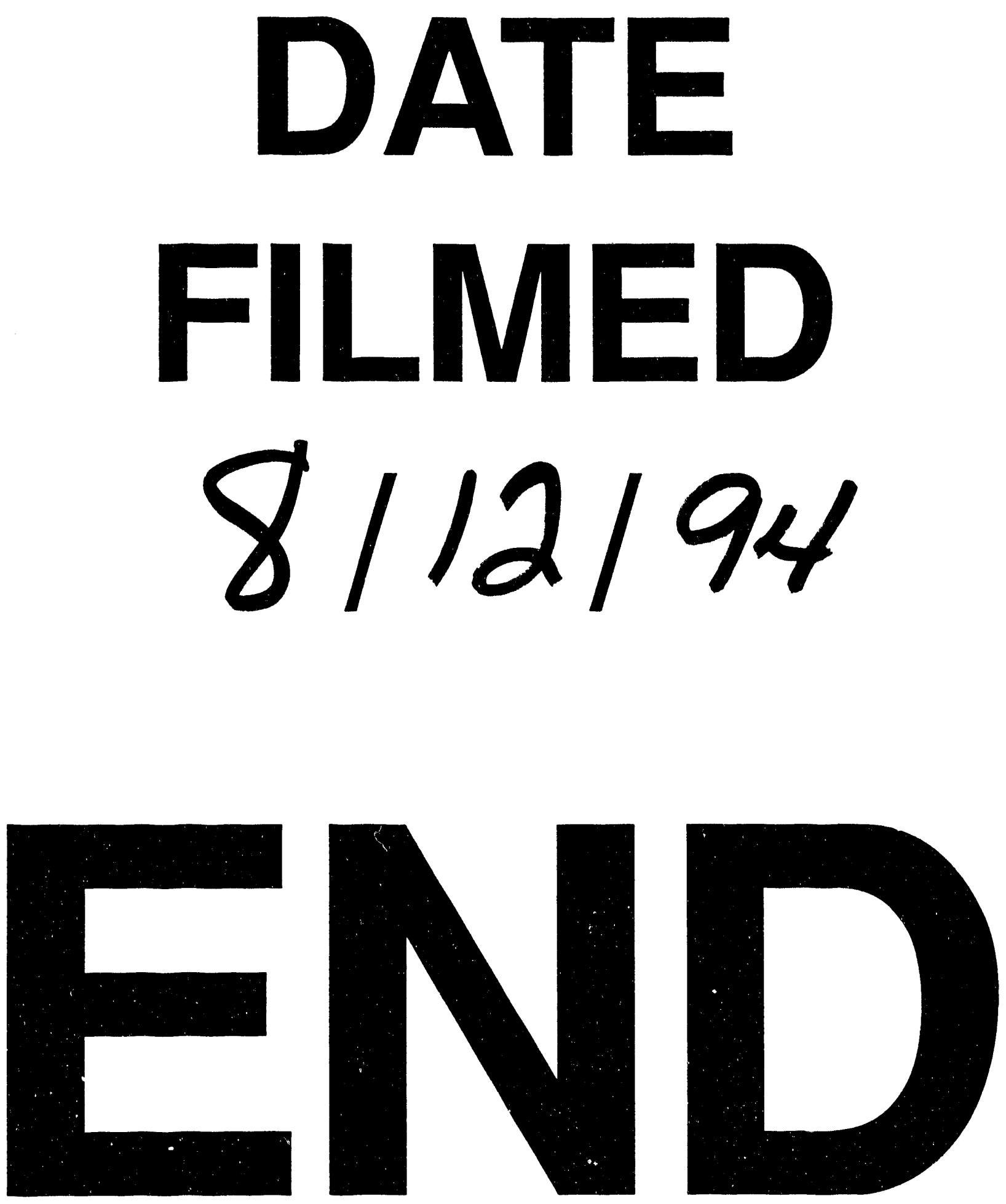